\title{
Combinatorial sympathetic and cytotoxic T-lymphocyte-associated protein 4 (CTLA-4) blockades inhibit the murine melanoma growth by targeting infiltrating $T$ cells
}

\author{
Bin Wang ${ }^{1,2}$, Zhifang $\mathrm{Xu}^{1,3,4}$, Nuchsupha Sunthamala ${ }^{3,5}$, Tomonori Yaguchi ${ }^{3}$, Jin Huang ${ }^{1}$, \\ Yutaka Kawakami ${ }^{3}$, Yinan Gong ${ }^{1}$, Huiling Tang ${ }^{1}$, Shanshan $\mathrm{Li}^{1}$, Yi Guo ${ }^{1,6}$, Yongming Guo ${ }^{1,4}$, \\ Masahisa Jinushi ${ }^{3}$
}

${ }^{1}$ Research Center of Experimental Acupuncture Science, Tianjin University of Traditional Chinese Medicine, Tianjin, China; ${ }^{2}$ Tianjin Medical University Cancer Institute and Hospital, National Clinical Research Center for Cancer, Key Laboratory of Cancer Prevention and Therapy, Tianjin's Clinical Research Center for Cancer, Tianjin, China; ${ }^{3}$ Division of Cellular Signaling, Institute for Advanced Medical Research, Keio University School of Medicine, Tokyo, Japan; ${ }^{4}$ School of Acupuncture \& Moxibustion and Tuina, Tianjin University of Traditional Chinese Medicine, Tianjin, China; ${ }^{5}$ Department of Biology, Faculty of Science, Mahasarakham University, Mahasarakham, Thailand; ${ }^{6}$ School of Traditional Chinese Medicine, Tianjin University of Traditional Chinese Medicine, Tianjin, China

Contributions: (I) Conception and design: M Jinushi, Z Xu; (II) Administrative support: M Jinushi, Z Xu; (III) Provision of study materials or patients: M Jinushi, T Yaguchi, Y Kawakami; (IV) Collection and assembly of data: M Jinushi, Z Xu, B Wang, T Yaguchi; (V) Data analysis and interpretation: M Jinushi, Z Xu, B Wang, T Yaguchi; (VI) Manuscript writing: All authors; (VII) Final approval of manuscript: All authors.

Correspondence to: Zhifang $\mathrm{Xu}, \mathrm{PhD}$. School of Acupuncture \& Moxibustion and Tuina, Tianjin University of Traditional Chinese Medicine, No. 10 Poyang Lake Road, Tuanbo New Town, Jinghai District, Tianjin 301617, China. Email: xuzhifangmsn@hotmail.com; Masahisa Jinushi, PhD. Division of Cellular Signaling, Institute for Advanced Medical Research, Keio University School of Medicine, 35 Shinanomachi, Shinjuku, Tokyo 160-8582, Japan. Email: mjinushi0412@gmail.com.

Background: Failure of the proliferation and infiltration of tumor-specific $T$ cells in tumor site has been considered as one of important reasons induce the inefficiencies of immune checkpoint therapies in advanced cancers. Therefore, we aimed to demonstrate how combinatorial sympathetic and cytotoxic T-lymphocyteassociated protein 4 (CTLA-4) blockade affects the tumor growth of melanoma-bearing mice and potential mechanisms.

Methods: Tumor growth was measured and the infiltrating immune cell populations were observed with flow cytometry in B16-F10 melanoma-bearing mice treated with combined sympathetic and immune checkpoint blockade, using anti-CTLA-4 antibodies. The expression of adrenergic receptors was investigated in human peripheral blood mononuclear cells and their subpopulations, and the proliferation of $\mathrm{T}$ cell subsets was detected when stimulated by norepinephrine and its antagonists.

Results: B16-F10 tumor growth was associated with infiltrating $\mathrm{CD} 8^{+} \mathrm{T}$ cells. Combinatorial sympathetic and CTLA-4 blockade inhibited tumor growth and enhanced CD8 ${ }^{+}$infiltration. Meanwhile, all $\beta 1, \beta 2$ and $\beta 3$ adrenergic receptors were found to be expressed in human peripheral blood mononuclear cells, activated $\mathrm{T}$ cells, monocytes, and monocyte-induced dendritic cells. $\beta 2$-adrenergic receptors were expressed in most $\mathrm{CD}^{+} \mathrm{T}$ cells with increased expression in activated $\mathrm{CD}^{+} \mathrm{T}$ cells. Moreover, norepinephrine was able to prevent $\mathrm{CD}^{+} \mathrm{T}$ cell proliferation and $\beta 2$-adrenergic receptor antagonists could reverse the inhibition of $\mathrm{CD}^{+}$, but not $\mathrm{CD}^{+}$cell proliferation.

Conclusions: We conclude that the combination of sympathetic and CTLA-4 inhibitors is more effective for inhibiting melanoma progression than a single treatment and might enhance the infiltration of $\mathrm{T}$ cells in the tumor site, offering a novel therapeutic approach for immune checkpoint targeting.

Keywords: Sympathetic nerve system; cytotoxic T-lymphocyte-associated protein 4 inhibitor (CTLA-4 inhibitor); melanoma; T cells; $\beta 2$-adrenergic receptor 
Submitted Aug 16, 2020. Accepted for publication Dec 11, 2020.

doi: $10.21037 /$ tcr-20-2738

View this article at: http://dx.doi.org/10.21037/tcr-20-2738

\section{Introduction}

Cancer is the result of cells growing abnormally, ultimately spreading to other regions of the body and interfering with normal physiology. Rates of death associated with cancer are increasing, and as such, it is vital that novel treatments for managing cancers be developed (1). Chronic stress and depression are common among cancer patients owing to the incurable nature of the disease (2). The sympathetic nervous system (SNS) can be activated by such chronic stress, leading to the release of specific neurotransmitters and neuropeptides that act through specific receptors on tumor cells and stromal cells to influence cancer progression and metastasis by altering cellular physiology (3-5). As such, pharmacologic compounds capable of antagonizing the SNS represent a potentially valuable therapeutic strategy, with multiple epidemiological studies having found $\beta$-adrenergic antagonist administration to delay the progression of prostate (6), breast $(7,8)$, lung (9), and ovarian (10) cancers, and malignant melanoma (11).

Previous studies have highlighted a wide range of mechanisms whereby specific cellular pathways can influence the ability of the SNS to affect tumor progression, altering processes ranging from oncogenesis to angiogenesis, as well as tumor cell growth and apoptosis $(12,13)$. Although many studies have explored how the SNS is associated with the immune system, the specific roles of these interactions in the context of the tumor-associated immune response are only recently being studied (14). Macrophages, natural killer (NK) cells, and T cells all have the potential to mediate SNS-induced regulation of tumors, as these cells each express different adrenergic receptors (ARs) (15). However, the essence of SNS regulation of tumor infiltration by immune cells remains unclear.

Many novel treatment strategies for cancers have been developed in recent decades. With the development of tumor immuno-therapies and immune checkpoint therapy, enhancement of antitumor immune responses by targeting $\mathrm{T}$ cells has offered a novel means of combatting cancer, resulting in durable long-term responses in many patients (16). Agents targeting $\mathrm{T}$ cell immune checkpoints such as cytotoxic T-lymphocyte-associated protein 4 (CTLA-4), programmed cell death-1 (PD-1), and programmed cell death-ligand 1 (PD-L1) have been shown to be effective in many clinical trials $(17,18)$. For instance, the treatment with anti-CTLA-4 antibodies or agents that directly kill tumor cells to release antigens for presentation by antigenpresenting cells (APCs) to T cells would improve antitumor responses. This approach led to the development of ipilimumab, an antibody against human CTLA-4, which resulted in considerable improvement in the overall survival of patients with metastatic melanoma and approval by the Food and Drug Administration in 2011. However, while promising, most patients treated only with immune checkpoint therapy fail to achieve complete responses. One reason could be that $T$ cell activation is dependent upon a range of intrinsic stimulatory and inhibitory signaling activities and the severe tumor immune-suppressive microenvironment inhibits the proliferation, migration, and survival of infiltrating $\mathrm{T}$ cells, potentially constraining $\mathrm{T}$ cell responses against different tumor types (17).

Given that mono-therapeutic immune checkpoint targeting is often limited in efficacy, the simultaneous targeting of multiple pathways through combination treatment has been explored in a range of cancer types with significant benefits to survival in many patients. For example, a phase I clinical trial that $53 \%$ of patients treated with combined anti-CTLA- 4 and anti-PD- 1 in advanced melanoma achieved an objective response, all with tumor reduction of regression in about half of the patients, with regression of at least $80 \%$ in most cases $80 \%$ or more (19). Combining anti-CTLA-4 with vaccination strategies has also shown promise in treating traditionally nonimmunogenic pancreatic cancer (20). Such combinatorial immunotherapy is believed to be essential for achieving optimal anti-tumor immunity in most cancer patients (17).

In view of the immune-suppressive micro-niche in the tumor and immune-suppressive effects of the SNS, we explored the effects of combinatorial sympathetic and CTLA-4 blockade on tumor growth in a murine melanoma model. We also investigated the possible mechanism involved in targeting the tumor immune micro-environment, aiming to establish a promising novel combinatorial immunotherapeutic intervention for tumor treatment.

We present the following article in accordance with the 
ARRIVE reporting checklist (available at http://dx.doi. org/10.21037/tcr-20-2738).

\section{Methods}

The study was conducted in accordance with the Declaration of Helsinki (as revised in 2013). The study was approved by the Human Ethics Committee of Keio University Medical School (No. 2013-0122-3) and informed consent was taken from all the patients. Experiments were performed under a project license [NO.: 09006-(8)] granted by the Institutional Animal Care and Use Committee of Keio University for the care and use of animals.

\section{Mice}

Eight-week-old female C57/BL6 mice weighing between 20 and $22 \mathrm{~g}$ were housed at Keio University under specific pathogen-free conditions and were maintained on 12-h light/dark cycle, $24^{\circ} \mathrm{C}$, and $40-50 \%$ humidity conditions, with free access to food and water.

\section{Tumor cell transplantation, treatment, and measurement}

B16-F10 cells were obtained from the American Type Culture Collection, with the Central Institute for Experimental Animals (Kawasaki, Japan) validating the identity of these cells by PCR to ensure a lack of contamination within the 3 months prior to their utilization in this study. We subcutaneously implanted $1 \times 10^{5}$ B16-F10 cells into WT C57BL/6 mice on the right flank, measuring tumor growth, the mice were randomly divided into four groups. Anti-PD-1 monoclonal antibody (mAb) $(0.5 \mathrm{mg}$ per dose per mouse, Clone RMP1-14, BioXCell, NH, USA) or anti-CTLA-4 mAb (0.5 mg per dose per mouse, Clone 9D9, BioXCell, NH, USA) or 6-hydroxydopamine (6OHDA, Sigma; $100 \mathrm{mg} / \mathrm{kg}$ on day $0,250 \mathrm{mg} / \mathrm{kg}$ on day 2) were administered intra-peritoneally to different groups of mice during the experimental period. Tumor volumes were measured using a digital caliper every 2 days after chemotherapy according to the formula: volume $\left(\mathrm{mm}^{3}\right)=$ width $2\left(\mathrm{~mm}^{2}\right) \times$ length $(\mathrm{mm}) / 2$.

\section{Flow cytometry (FCM) assay}

Tumors and spleens were collected from the B16-F10bearing mice 21 days post-tumor cell transplantation. The tumor tissue was cut into pieces and digested with $1 \mathrm{mg} / \mathrm{mL}$ collagenase IV and $150 \mathrm{U} / \mathrm{mL}$ DNase I in RPMI-1640 for $1 \mathrm{~h}$ at $37^{\circ} \mathrm{C}$ with shaking. The spleen tissue was passed through a mesh to collect single cells. After lysis of the red blood cells, $1.0 \mu \mathrm{g}$ anti-mouse CD16/CD32 (BD Pharmingen) in 2.0\% FBS was added for $10 \mathrm{~min}$ to block endogenous non-specific binding to Fc receptors. Mononucleated cells $\left(5 \times 10^{6}\right.$ cells $)$ were combined with fluorescein isothiocyanate (FITC)-labeled CD8a, phycoerythrin (PE)-labeled CD45, allophycocyanin labeledCD3, pacific blue-labeled CD4 and PE-CY7 CD11b (Biolegend, San Diego, CA, USA) for $30 \mathrm{~min}$ at room temperature. In the $\beta 2-\mathrm{AR}$ staining setting, mononucleated cells were incubated with rabbit anti- $\beta 2-A R$ antibodies (Santa Cruz, Dallas, TX, USA), allophycocyanin labeledCD3, PE-labeled CD8a, and Pacific Blue-labeled CD4 (Biolegend, San Diego, CA, USA) for $30 \mathrm{~min}$ at room temperature and then stained with FITC-goat anti-rabbit IgG F(ab')2 fragments (Jackson Immunoresearch, West Grove, PA, USA) for $30 \mathrm{~min}$. Finally, the fluorescence of the cell suspension was assessed with a Gallios (Beckman Coulter, CA, USA), using Kaluza software (Beckman Coulter) for data analysis.

\section{Preparation of spleen and tumor sections and immunofluorescent (IF) staining}

B16-F10-bearing mice were anesthetized with sodium pentobarbital. The tumors and spleens were removed and fixed with ice-cold $4 \%$ paraformaldehyde (PFA, $\mathrm{pH}$ 7.4) at $4{ }^{\circ} \mathrm{C}$ and frozen blocks prepared. The blocks were sliced into $10.0 \mu \mathrm{m}$ sections. In the IF staining process, sections were rinsed in PBST prior to permeabilization for 30 min using $0.25 \%$ Triton $\mathrm{X}-100$, and were then blocked in $10 \%$ normal horse serum (NHS, Vector Laboratories, Burlingame, CA, USA) followed by overnight probing using rabbit antityrosine hydroxylase (TH, Chemicon, Temecula, CA, USA) or anti-neurofilament 200 (NF-200, Sigma-Aldrich) at $4{ }^{\circ} \mathrm{C}$. Next, secondary antibodies labeled with AF488 (1:400; Invitrogen, Thermo Fisher, San Diego, CA, USA) were used to treat samples for $60 \mathrm{~min}$, and then DAPI (SigmaAldrich) was used to stain nuclei.

When staining multiple markers, after blocking, samples were probed overnight at $4{ }^{\circ} \mathrm{C}$ with NF-200 and/or fluorochrome-labeled antibodies against the hematopoietic cell marker CD45 and the T cell marker CD8. Samples were then washed and stained with secondary antibodies/ DAPI as above, followed by imaging with an LSM700 Laser Scanning Microscope (Carl Zeiss, Germany). 
Table 1 The gene-specific primers used in this study

\begin{tabular}{lcccc}
\hline Gene & Forward primer $\left(5^{\prime} \rightarrow 3^{\prime}\right)$ & Reverse primer $\left(5^{\prime} \rightarrow 3^{\prime}\right)$ & Product size \\
\hline Adrb1 & CTACAACGACCCCAAGTGCT & ATCTTCTTCACCTGCTTCTGGG & 147 \\
Adrb2 & TTCCATGTCCAGAACCTTAGCC & AAGTGCCCATGATGATGCCTAA & 127 \\
Adrb3 & CTTGGGTCTCATCATGGGCAC & GCATAACCTAGCCAGTTCAGGG & 132 \\
$\beta$-actin & GGCATCCACGAACTACCTT & ATCTCCTTCTGCATCCTGTCG & 134 \\
\hline
\end{tabular}

\section{Tell polarization}

The collection of blood and the experiments using the blood that are reported here received approval from the Human Ethics Committee of Keio University Medical School (Permit No. 2013-0122-3). Blood was obtained after informed consent from two normal healthy donors (HLA-A2). Peripheral blood mononuclear cells (PBMCs) were collected using Ficoll-Paque (GE Healthcare). Antihuman CD14 Microbeads (Miltenyi Biotec, Bergisch Gladbach, Germany) were used to positively enrich for monocytes, which were transduced into $\mathrm{CD} 14^{+}$monocytederived myeloid cells (CD14-ML) by using lentiviral vectors, which were then differentiated into dendritic cells as described previously (21), PBMC were stimulated with antiCD3 $(50 \mathrm{ng} / \mathrm{mL}) / \mathrm{IL}-2(500 \mathrm{IU} / \mathrm{mL})$ monoclonal antibodies for 7 days. The cells were collected at indicated time points (days $0,4,7$ ) for FCM analysis as described above.

\section{Reverse transcription-polymerase chain reaction (RT-PCR)}

First, mRNA was obtained from treated cells and RT-PCR was conducted as previously described (22). Table 1 lists all the primers used. The negative control did not receive reverse transcriptase. AR subtype mRNA expression was observed with the GelDoc 2000 gel imaging system (BIORAD, Hercules, CA, USA)

\section{Carboxyfluorescein succinimidyl ester (CFSE) assay}

PBMCs were treated using anti-CD3 $(50 \mathrm{ng} / \mathrm{mL})$ and antiIL-2 $(500 \mathrm{IU} / \mathrm{mL})$ monoclonal antibodies as well as with norepinephrine (NE, final concentration $10^{-9} \mathrm{M}, 10^{-8}$ and $10^{-7} \mathrm{M}$ ) and timolol maleate (final concentration $2 \times 10^{-9}$, $2 \times 10^{-8}$, and $2 \times 10^{-7} \mathrm{M}$, Sigma-Aldrich) in AIM-V medium with $10 \%$ human $\mathrm{AB}$ serum for 7 days. We then harvested and stained the cells with CFSE staining solution $(1: 1,000$, Thermo Fisher Scientific, CA, USA), PE-labeled CD8a and Pacific Blue-labeled CD4 for FCM analysis as described above.

\section{Statistical analysis}

Data are expressed as means \pm standard error of the mean (SEM). Repeated measures and multivariate ANOVAs were used for comparing groups over time and multiple groups, as appropriate, with least significant difference (LSD) or Dunnett's T3 methods being used based on the homogeneity of variance testing. SPSS 19.0 was used for statistical testing.

\section{Results}

Anti-PD-1 and anti-CTLA-4 antibodies affect tumor growth and T cell infiltration in B16-F10-bearing mice

In the preliminary experiment, B16-F10 cells at $1 \times 10^{5}$ and $1 \times 10^{6}$ were subcutaneously implanted in WT C57BL/6 mice. And it was found that mice treated with the dose of $1 \times 10^{6}$ cells showed a rapid tumor growth and a high mortality in 2-3 weeks. Although the tumor growth with B16-F10 cells transplanted at $1 \times 10^{5}$ was relatively slow in the first 10 days, tumor began to grow rapidly from the 11th day. Most of the tumor-bearing mice had a long survival time more than 3 weeks, thus we chose B16-F10 cells at $1 \times 10^{5}$ for the current study. To confirm the best administrative schedule for anti-PD-1/CTLA-4, we observed the tumor growth in B16-F10-bearing mice $(\mathrm{n}=8)$ under different administrative schedules as shown in Figure $1 A$. As shown in Figure 1B, anti-CTLA-4 treatment at days 1, 4 and 7 showed better tumor growth inhibition tendency compared with the vehicle group and the other treatment groups at day 21 ( $\mathrm{n}=2$ each group). Meanwhile, the correlation of tumor size on day 21 and tumor infiltration or splenic immune cell sub-population was analyzed and found that the tumor size was negatively correlated with infiltrating $\mathrm{CD} 45^{+} \mathrm{CD}^{+}$(Pearson correlation analysis, $\mathrm{r}=-0.78, \mathrm{r}^{2}=0.61$, $\mathrm{P}<0.05$, Figure $1 C$ ), particularly highly negatively correlative 
A

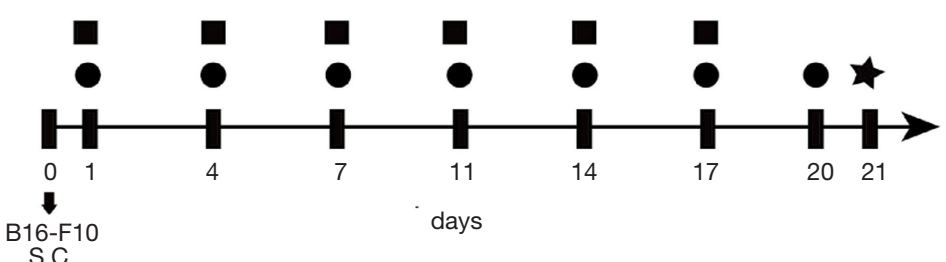

S.C.

aPD-1 d1-4-7, aCTLA-4 d1-4-7, aPD-1 d11-14-17

Tumor size

Collect tumor and spleen

C

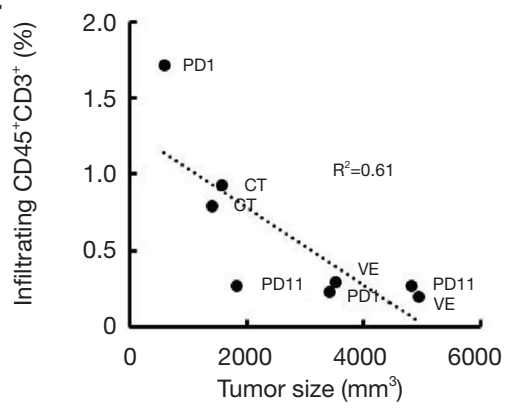

$\mathrm{F}$

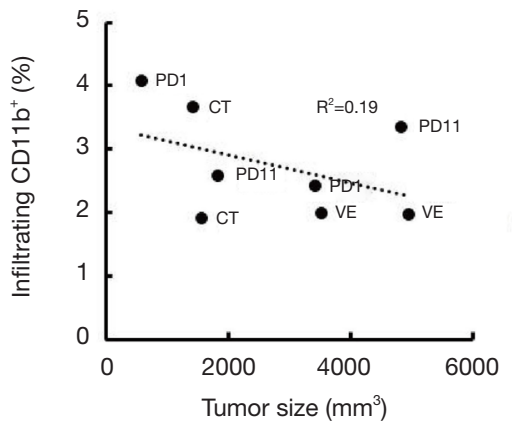

D

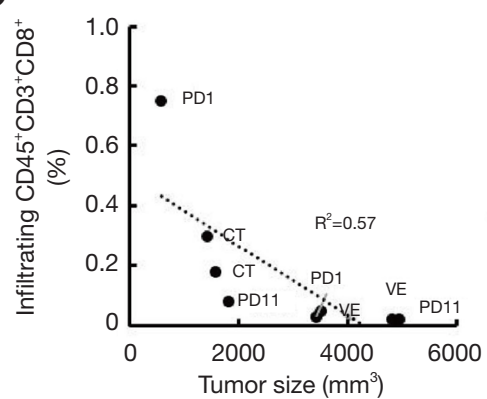

G

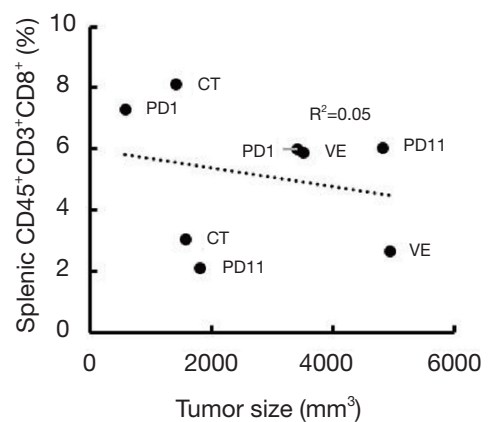

E

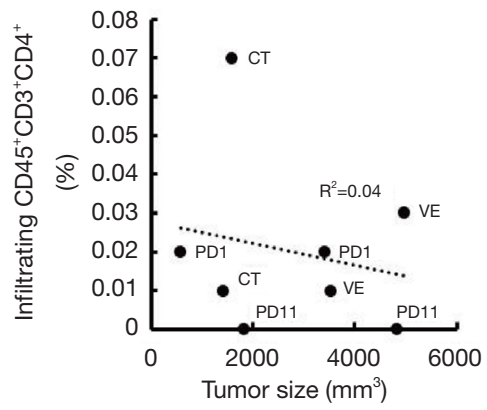

$\mathrm{H}$

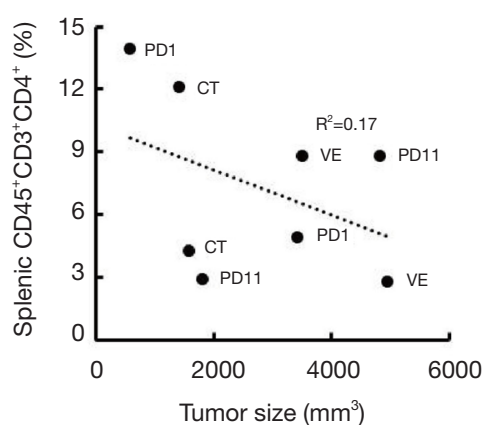

Figure 1 The effect of anti-PD-1 and anti-CTLA-4 antibodies on the tumor growth in B16-F10-bearing mice. (A) A schematic diagram illustrating the chronological events of experiments (n=8). (B) Tumor growth kinetics in anti-PD-1 day 1-4-7, anti-PD-1 day 11-14-17 or anti-CTLA-4 day 1-4-7 treated B16-F10-bearing mice, compared with vehicle (n=2). Data are mean \pm SEM. (C,D,E,F,G,H) The correlation of tumor size and tumor-infiltrating and splenic immune cell population infiltrating $\mathrm{CD} 45^{+} \mathrm{CD} 3^{+}(\mathrm{C}), \mathrm{CD} 45^{+} \mathrm{CD} 3^{+} \mathrm{CD} 8^{+} \mathrm{T}$ cells $(\mathrm{D})$, $\mathrm{CD}^{+} 5^{+} \mathrm{CD} 3{ }^{+} \mathrm{CD}^{+} \mathrm{T}$ cells $(\mathrm{E})$ and $\mathrm{CD} 45^{+} \mathrm{CD} 11 \mathrm{~b}^{+}$myeloid cells $(\mathrm{F})$, splenic $\mathrm{CD}^{+} 5^{+} \mathrm{CD} 3^{+} \mathrm{CD} 8^{+}(\mathrm{G})$ and $\mathrm{CD} 45^{+} \mathrm{CD} 3{ }^{+} \mathrm{CD} 4^{+} \mathrm{T}$ cells $(\mathrm{H}) . \mathrm{VE}$, vehicle; PD1, anti-PD-1 day 1-4-7; PD11, anti-PD-1 day 11-14-17; CT, anti-CTLA-4 day 1-4-7; PD-1, programmed cell death-1; CTLA4, cytotoxic T-lymphocyte-associated protein 4.

with infiltrating $\mathrm{CD} 45^{+} \mathrm{CD} 3^{+} \mathrm{CD} 8^{+} \mathrm{T}$ cell population $\left(\mathrm{r}=-0.76, \mathrm{r}^{2}=0.57, \mathrm{P}<0.05\right.$, Figure $\left.1 D\right)$; but not correlated with infiltrating $\mathrm{CD} 45^{+} \mathrm{CD} 3^{+} \mathrm{CD} 4^{+} \mathrm{T}$ cells, $\mathrm{CD} 45^{+} \mathrm{CD} 11 \mathrm{~b}+$ myeloid cells and splenic $\mathrm{T}$ cell subsets (Figure 1E,F,G,H). Furthermore, the infiltrating $\mathrm{T}$ cell populations were compared by FCM between different treatment groups as shown in Figure 2A,B. Groups treated with anti-PD-1 and anti-CTLA-4 at days 1, 4 and 7 showed increased tendency of $\mathrm{CD} 45^{+} \mathrm{CD}^{+}$and $\mathrm{CD} 45^{+} \mathrm{CD}^{+}{ }^{+} \mathrm{CD}^{+}{ }^{+} \mathrm{T}$ cells $(\mathrm{n}=2)$. In accordance with the FCM results, the anti-CTLA-4 1-4-7 group also displayed more $\mathrm{CD} 8^{+}$-and $\mathrm{CD} 45^{+} \mathrm{CD} 8^{+}$-labeled cells in the tumor parenchyma as visualized by IF staining compared with the vehicle group, although the intensity of the $\mathrm{CD} 45^{+}$population appeared similar in the two groups (Figure $2 C, D$ ). These results indicated that administration of the anti-CTLA-4 antibody at days 1, 4 and 7 resulted in better inhibition of tumor growth as well as enhancement of infiltrating cytotoxic $\mathrm{T}$ cell at the tumor site. We, therefore, chose the anti-CTLA antibody treatment at days 1, 4 and 7 for the following study. 

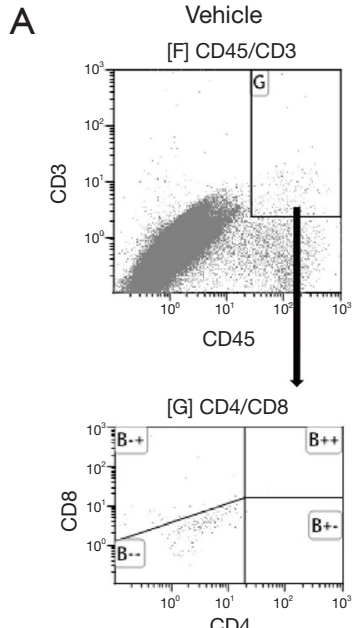

B

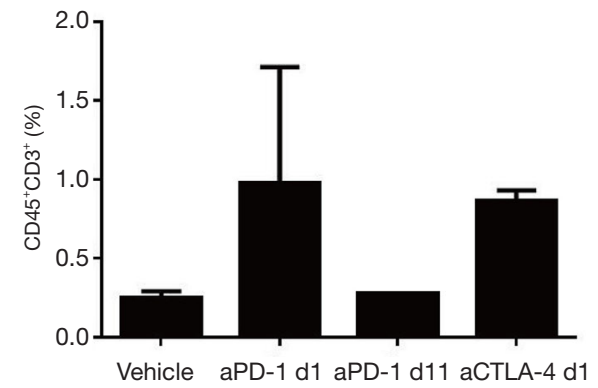

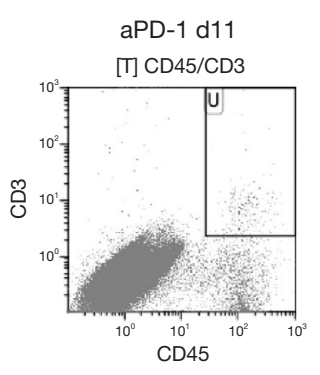
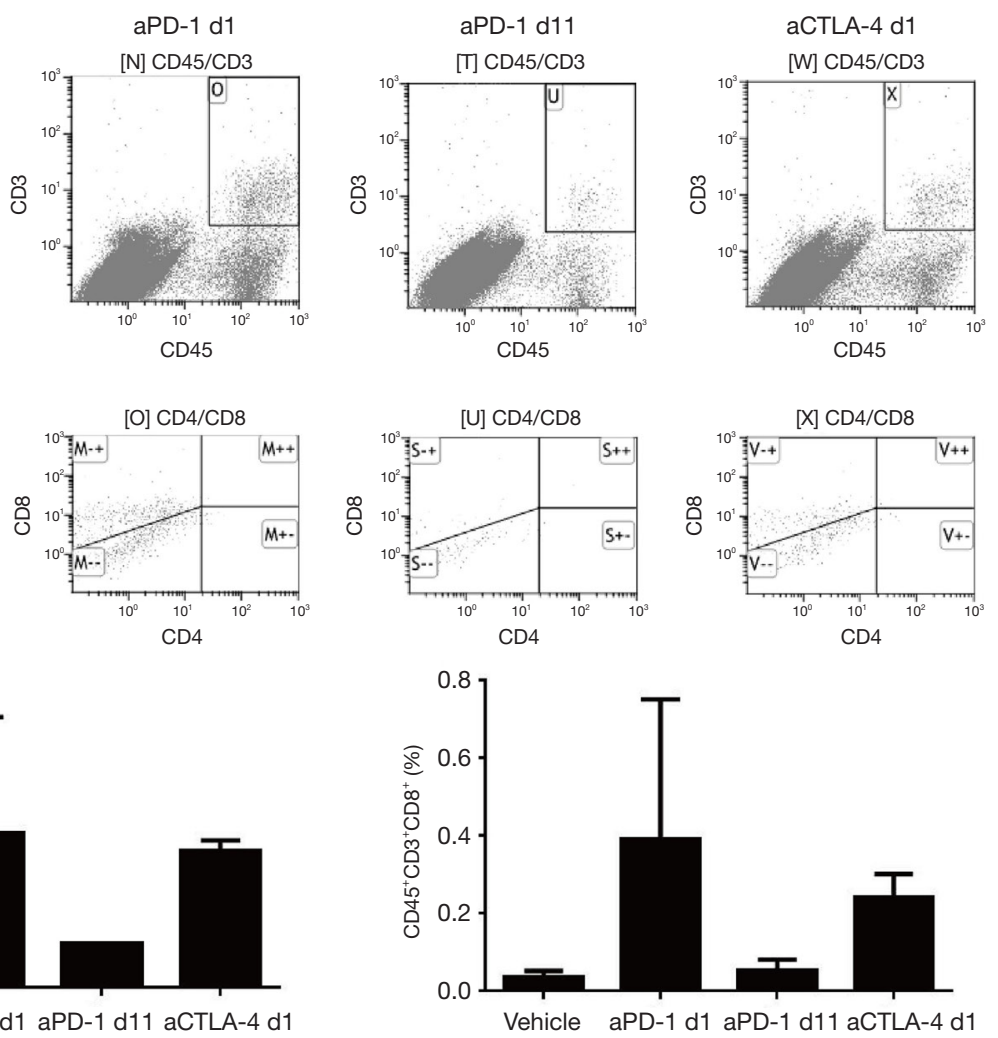

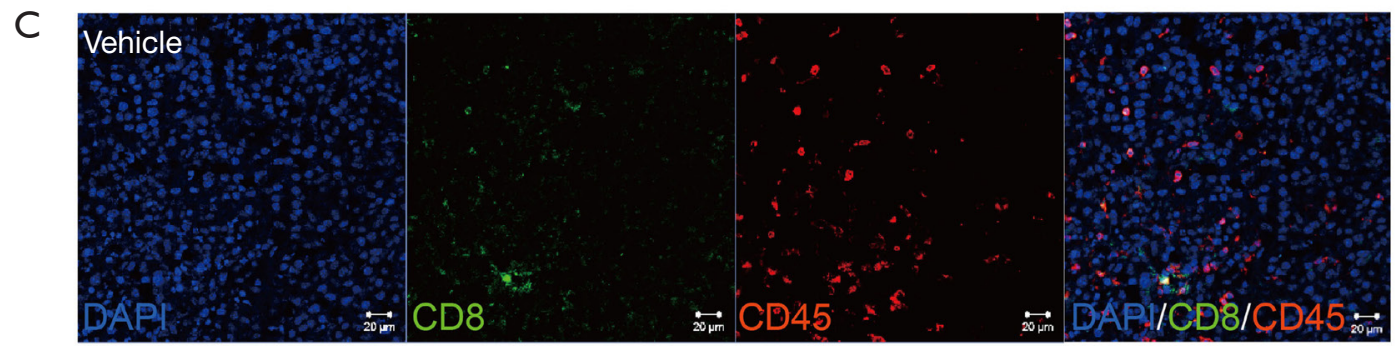

D

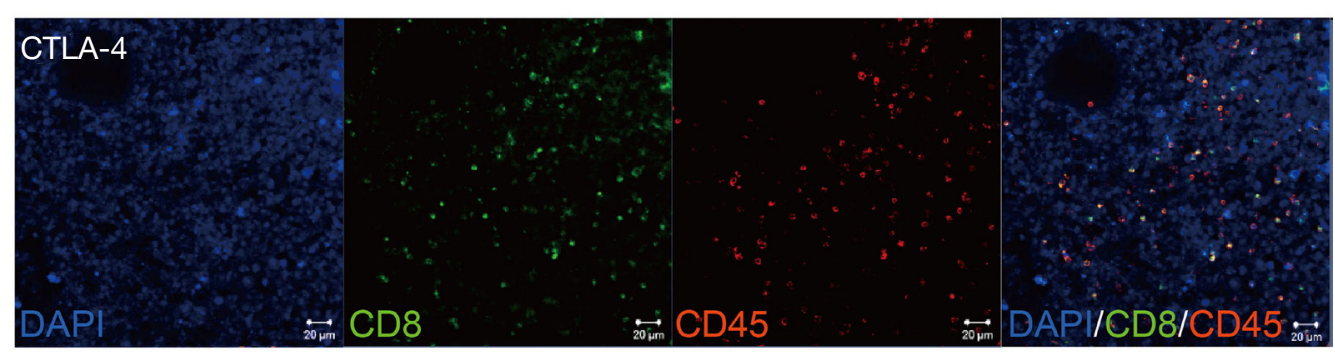

Figure 2 The effect of anti-PD-1 and anti-CTLA-4 antibodies on the infiltrating T cell population in B16-F10-bearing mice. (A) Dot plots depicting live cell-gated $\mathrm{CD} 45^{+} \mathrm{CD}^{+}{ }^{+} \mathrm{CD}^{+}$and $\mathrm{CD} 45^{+} \mathrm{CD}^{+} \mathrm{CD}^{+} \mathrm{T}$ cell proportions in the tumor of B16-F10-bearing mice $(\mathrm{n}=8)$ in indicated treatments. (B) Quantification of $\mathrm{CD} 45^{+} \mathrm{CD}^{+}$and $\mathrm{CD} 45^{+} \mathrm{CD}^{+} \mathrm{CD} 8^{+} \mathrm{T}$ cell proportions in the tumor site of $\mathrm{B} 16-\mathrm{F} 10$-bearing mice in indicated treatment groups $(n=2)$, data are mean \pm SEM. $(C, D)$ Representative images of multiple staining with PE-labeled antiCD45, FITC-labeled anti-CD8 and DAPI in the tumor center region of vehicle (C) or anti-CTLA-4 mice (D). Scale bars, $20 \mu \mathrm{m}$. CTLA-4, cytotoxic T-lymphocyte-associated protein 4; SEM, standard error of the mean; FITC, fluorescein isothiocyanate. 

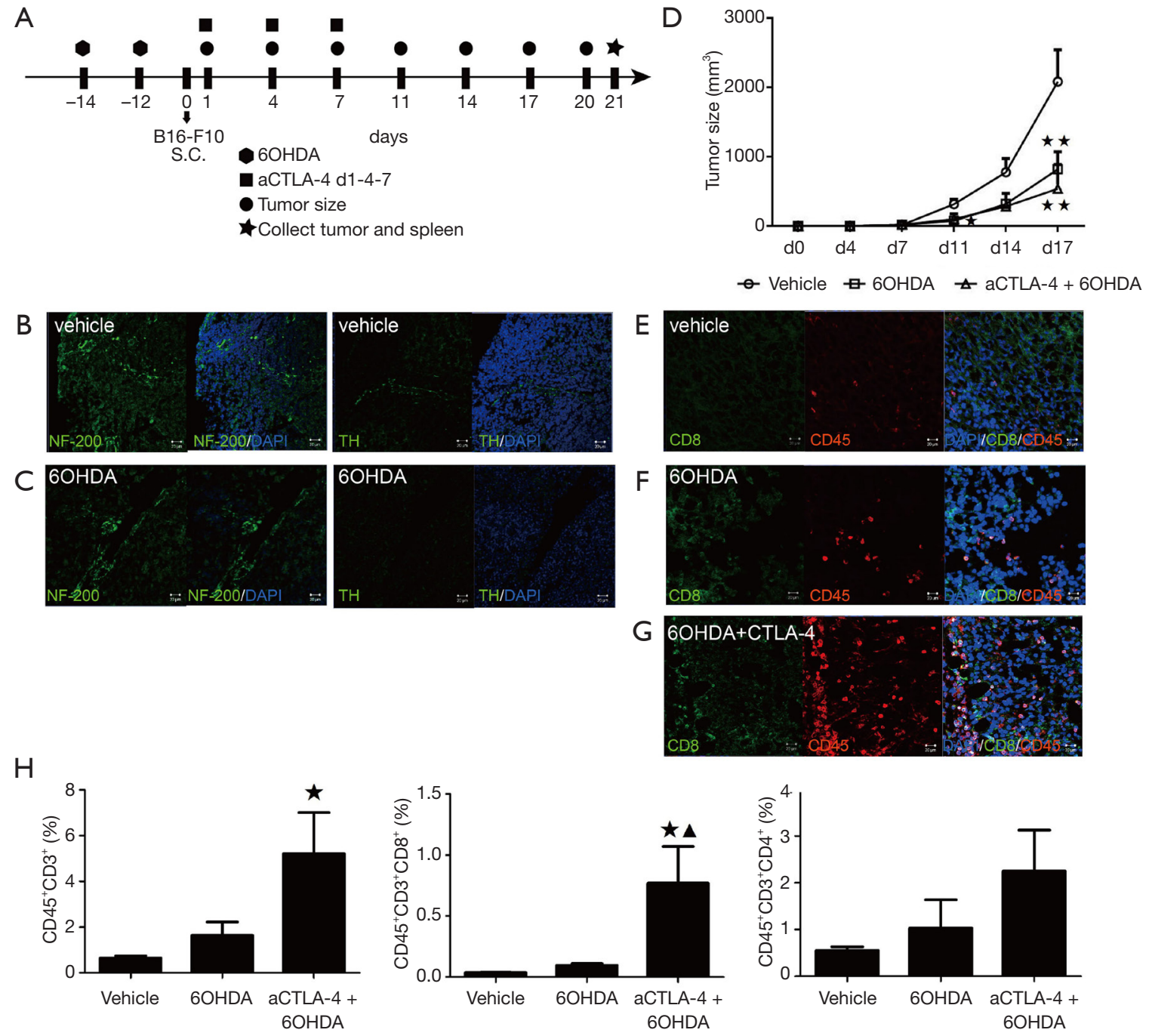

Figure 3 The combinatorial sympathetic and CTLA-4 blockade attenuate B16-F10 tumor growth and enhance T cells infiltration. (A) A schematic diagram illustrating the chronological events of experiments $(n=12)$. (B,C) Representative IF images of NF-200 or TH staining on two continuous splenic sections in vehicle (B) or 6OHDA treated mice (C). Scale bars, $20 \mu \mathrm{m}$. (D) Tumor growth kinetics in 6OHDA and combinatorial therapy (6OHDA + anti-CTLA-4 antibodies) treated B16-F10-bearing mice, compared with vehicle ( $\mathrm{n}=4)$. Data are mean \pm SEM. ${ }^{\star}, \mathrm{P}<0.05 ;{ }^{\star} \star{ }^{\star}, \mathrm{P}<0.01$ vs. vehicle. (E,F,G) Images of multiple staining with PE-labeled anti-CD45, FITC-labeled anti-CD8 and DAPI in the tumor center region of vehicle (E), 6OHDA (F) or 6OHDA + anti-CTLA-4 treated mice (G). Scale bars, $20 \mu \mathrm{m}$. (H) Quantification of $\mathrm{CD}_{4} 5^{+} \mathrm{CD}^{+}$and $\mathrm{CD} 45^{+} \mathrm{CD} 3^{+} \mathrm{CD} 8^{+} \mathrm{T}$ cell proportions in the tumor site of B16-F10-bearing mice in indicated treatment groups ( $\mathrm{n}=4$ ). Data are mean \pm SEM, ${ }^{\star}, \mathrm{P}<0.05$ vs. vehicle; ${ }^{\star}, \mathrm{P}<0.05$ vs. 6OHDA. 6OHDA, 6-hydroxydopamine; CTLA-4, cytotoxic T-lymphocyteassociated protein 4; IF, immunofluorescent; NF-200, neurofilament 200; TH, tyrosine hydroxylase; SEM, standard error of the mean; PE, phycoerythrin; FITC, fluorescein isothiocyanate.

\section{The effect of combinatorial sympathetic and CTLA-4 blockade on the tumor growth and T cell infiltration in B16-F10-bearing mice}

To explore the specific involvement of sympathetic innervation in the tumor micro-environment, we denervated the systemic sympathetic nerves using 6OHDA treatment two weeks before tumor transplantation because it took 3-5 days for 6OHDA to destroy nerve endings (23) (Figure $3 A$ ). Some sympathetic blockage symptoms in mice following 6OHDA injection were observed, such as pilo- 
A
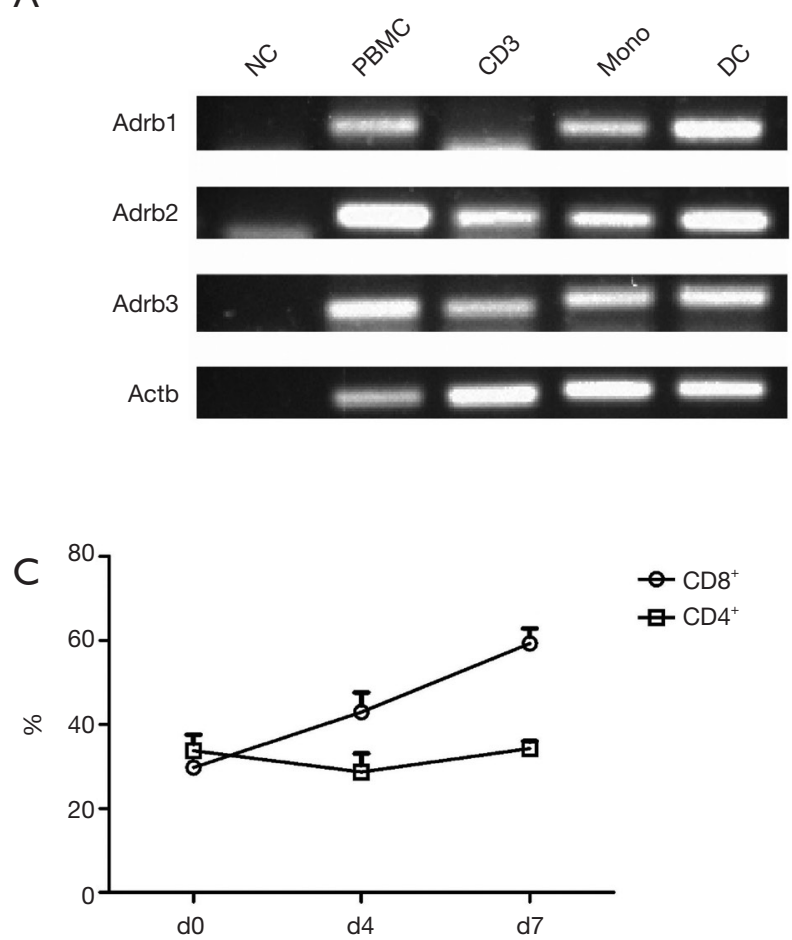

B

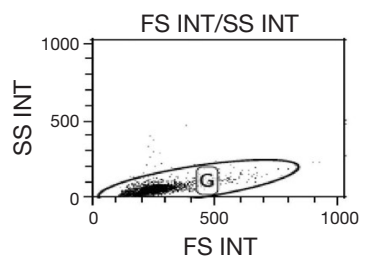

[C] b2-AR/CD8
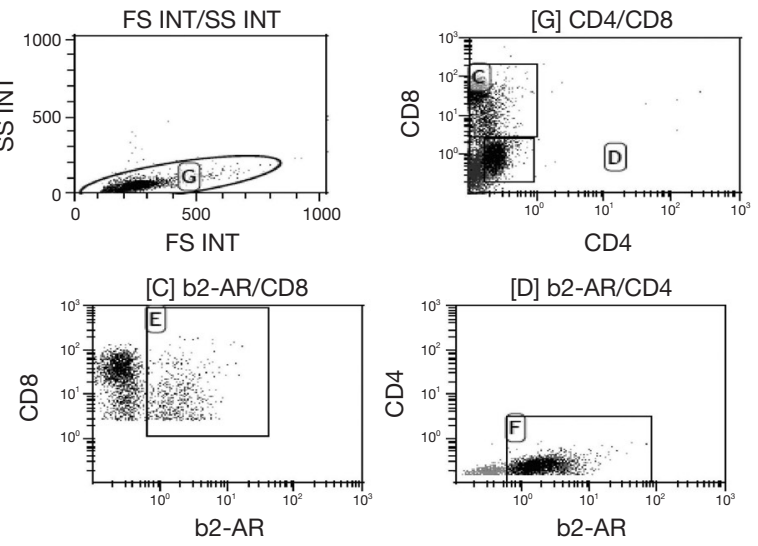

[D] b2-AR/CD4
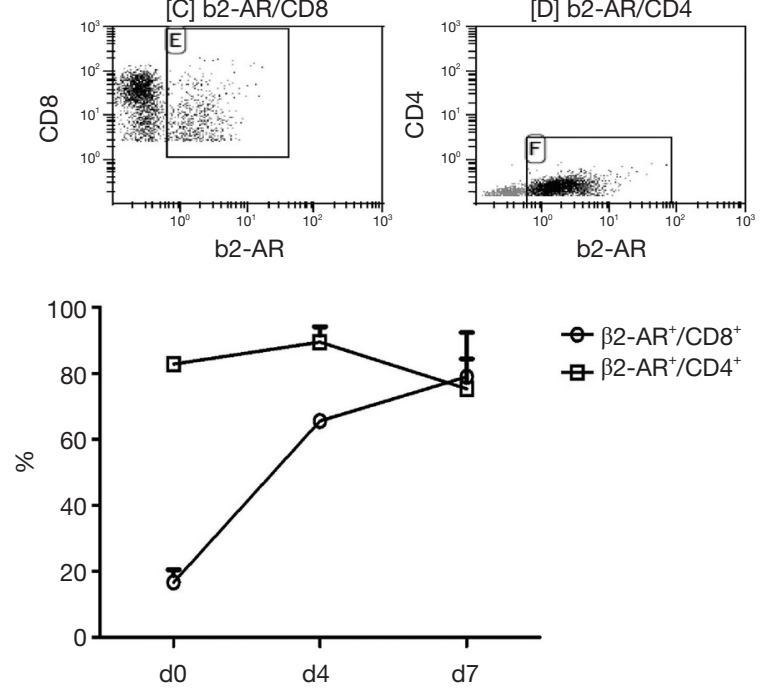

๑ $\beta 2-\mathrm{AR}^{+} / \mathrm{CD}^{+}$ $\rightarrow \beta 2-\mathrm{AR}^{+} / \mathrm{CD} 4^{+}$

Figure 4 The expression of $\beta$ adrenergic receptors (ARs) in immune cell sup-populations. (A) Expression of genes encoding $\beta 1$-, $\beta 2$ - and $\beta 3$-ARs in fresh human PBMC, CD3-stimulated PBMC, CD14 ${ }^{+}$peripheral monocyte, CD14 ${ }^{+}$monocyte-derived dendritic cells. RT-free indicates no reverse transcriptase (negative control). (B) Dot plots depicting live cell-gated $\mathrm{CD} 8^{+}$or $\mathrm{CD} 4^{+}$(the second panel) or $\mathrm{CD} 8^{+} \beta 2-\mathrm{AR}{ }^{+}$ (the third panel) or $\mathrm{CD}^{+} \beta 2-\mathrm{AR}^{+}$(the fourth panel) cell proportions in fresh PBMC. (C,D) Quantification of CD8 ${ }^{+}$or $\mathrm{CD} 4^{+}$cell proportions (C) before, 3 or 7 days after CD3 and IL-2 stimulation $(n=2)$. Data are mean \pm SEM. PBMC, peripheral blood mononuclear cell; SEM, standard error of the mean.

erection, ptosis of upper eyelid and exorbitism. NF-200 and TH staining showed spindle-like fibers in the same location on two continuous splenic sections of mice in the vehicle group (Figure 3B), while, although TH staining was absent on the splenic sections of the 6OHDA-treated mice, NF200-labeled fibers were observed (Figure 3C), indicating that the sympathetic nerves were denervated successfully. As shown in Figure $3 D$, the tumor size was reduced by single 6OHDA at day 17 ( $\mathrm{n}=4, \mathrm{P}<0.01$ vs. vehicle) compared with that vehicle groups, while combinatorial 6OHDA and CTLA-4 blockade at days 1, 4 and 7 inhibited the tumor growth earlier $(\mathrm{n}=4, \mathrm{P}<0.05 v s$. vehicle $)$ at day 11 and slight better $(\mathrm{n}=4, \mathrm{P}<0.01$ at day $17 v s$. vehicle, $\mathrm{P}>0.05$ vs. 6OHDA). Meanwhile, the IF results indicated greater numbers of infiltrating $\mathrm{CD} 45^{+} \mathrm{CD} 8^{+}$cells in the combinatorial groups compared with those in the vehicle group, and slightly increased numbers in the 6OHDA group (Figure $3 E, F, G$ ). Consistent with the histological results, FCM analysis showed that combinatorial therapy increased $\mathrm{CD}_{4} 5^{+} \mathrm{CD}^{+}(\mathrm{n}=4, \mathrm{P}<0.05$ vs. vehicle $)$ and $\mathrm{CD} 45^{+} \mathrm{CD} 3^{+} \mathrm{CD} 8^{+}(\mathrm{n}=4, \mathrm{P}<0.05$ vs. vehicle and $\mathrm{P}<0.05$ vs. 6OHDA) infiltration in the tumor parenchyma, while the $\mathrm{CD} 45^{+} \mathrm{CD} 3^{+} \mathrm{CD} 4^{+}$population showed some increase in the combinatorial group (Figure $3 H$ ). These results indicated that combinatorial sympathetic and CTLA-4 blockade could inhibit tumor growth and increase the numbers of infiltrating cytotoxic T cells in B16-F10-bearing mice.

\section{B2-AR signaling affects the proliferation of activated T cells}

NE serves as the primary terminal neurotransmitter released from postganglionic sympathetic nerve terminals and acts on target cells by binding to ARs on the cell surface. Therefore, we investigated the expression of $\beta$-ARs on several blood and immune cell populations of healthy donors. As shown in Figure $4 A, \beta 1-\mathrm{AR}, \beta 2-\mathrm{AR}$, and $\beta 3$ - 


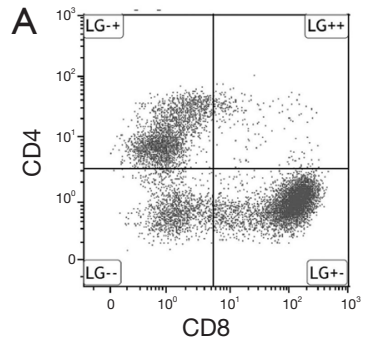

C
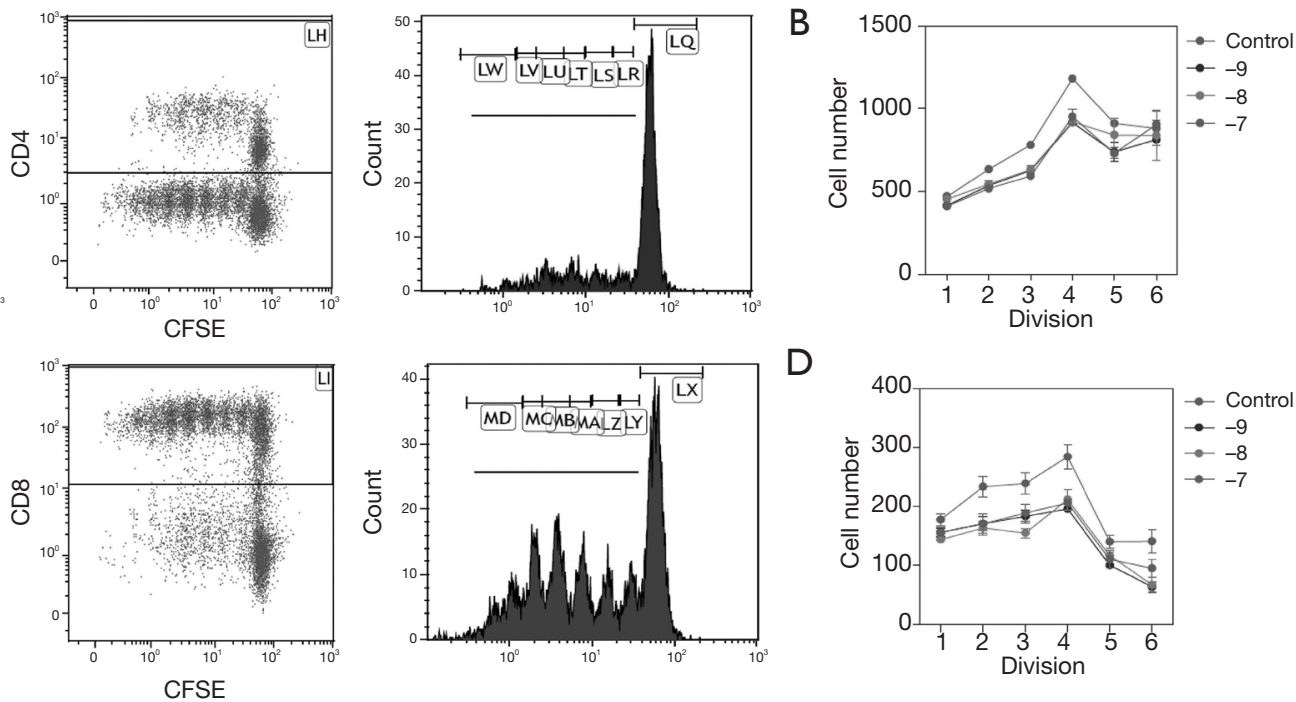

D

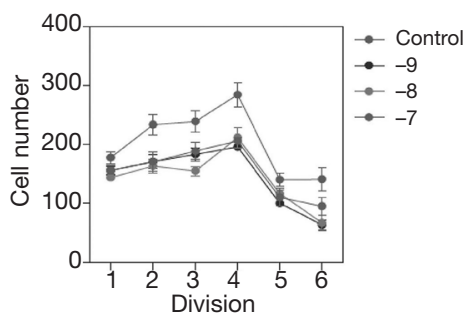

$\mathrm{F}$

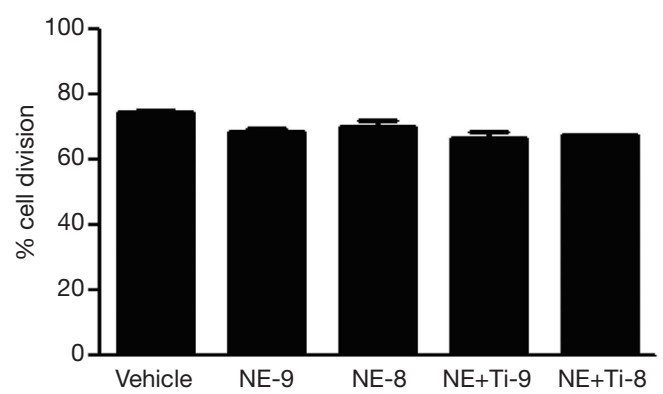

Figure 5 The effect of $\beta 2$-AR signaling on the proliferation of activated T cells. (A) The dot plots depicting the proliferation of cell-gated $\mathrm{CD}^{+}(\mathrm{A})$ or $\mathrm{CD}^{+}$proportions (C) by CSFE assay $(\mathrm{n}=2)$. (B,D) Quantification of proliferation $\mathrm{CD} 4^{+}(\mathrm{B})$ or $\mathrm{CD} 8^{+}(\mathrm{D})$ proportions by CSFE assay proportions. (E,F) The total proliferative percentage of $\mathrm{CD}^{+}(\mathrm{E})$ or $\mathrm{CD}^{+}(\mathrm{F})$ proportions in $\mathrm{PBMC}$ after 7-day stimulation with $\mathrm{NE}$ (final concentration $10^{-9}$ and $10^{-8} \mathrm{M}$ ) and/or timolol maleate (final concentration $2 \times 10^{-9}$ and $2 \times 10^{-8} \mathrm{M}$ ) in the presence of CD3 and IL-2 in the medium $(\mathrm{n}=3)$. Data are expressed as mean $\pm \mathrm{SEM}$. ${ }^{\star}, \mathrm{P}<0.05$. AR, adrenergic receptor; PBMC, peripheral blood mononuclear cell; NE, norepinephrine; SEM, standard error of the mean.

AR were strongly expressed in fresh PBMC, monocytes, and monocyte-derived dendritic cells. $\beta 2-\mathrm{AR}$ and $\beta 3$-AR were also highly expressed on CD3-stimulated PBMC. We then assessed the expression patterns of $\beta 2-A R$ on the subpopulations of $\mathrm{T}$ cells. As shown in Figure 4B,C, the fresh PBMCs of two healthy donors were stimulated by $\mathrm{CD} 3$ and IL-2 for 7 days, and the $\mathrm{CD} 8^{+} \mathrm{T}$ cell population increased from $29.8 \% \pm 1.2 \%$ on day 0 to $59.3 \% \pm 3.6 \%$ on day 7 , in other words, two-fold higher on day $7(n=2)$, while $\mathrm{CD}^{+} \mathrm{T}$ cell population did not change significantly $(33.8 \% \pm 3.8 \%$ on day $0,34.3 \% \pm 1.7 \%$ on day $7, n=2$, Figure $4 C$ ). Moreover, we determined the $\beta 2$-AR expression (shown in Figure $4 D$ ) in the subpopulations of $\mathrm{T}$ cells and found that the $\beta 2$-AR expression was markedly enhanced in $\mathrm{CD} 8^{+}$
T cells from $16.2 \% \pm 3.8 \%$ on day 0 to $79.1 \% \pm 13.4 \%$ on day $7(\mathrm{n}=2)$, while the $\mathrm{CD}^{+} \mathrm{T}$ cell population remained high $(82.9 \% \pm 0.9 \%$ on day $0,75.4 \% \pm 9.1 \%$ on day $7, n=2)$, indicating that $\mathrm{T}$ cells might be the regulatory target for the main sympathetic neurotransmitter NE.

Next, we determined the effects of $\beta 2$-AR signaling on the proliferation of activated T cells. When fresh PBMCs from two healthy donors were stimulated with $\mathrm{CD} 3$ and IL-2 as well as NE (final concentrations $10^{-9}, 10^{-8}$, and $10^{-7} \mathrm{M}, \mathrm{n}=3$ ) for 7 days, the proliferation in both $\mathrm{CD} 4^{+}$ cells (Figure $5 A, B$ ) and $\mathrm{CD}^{+}$(Figure 5C,D) cells appeared to have decreased compared to the control group at each dose, although no dose-dependent pattern was observed. The $\beta 2$-AR-specific antagonist timolol maleate (final 
concentrations $2 \times 10^{-9}$ and $\left.2 \times 10^{-8} \mathrm{M}\right)$ was then included in the medium $30 \mathrm{~min}$ before adding NE (final concentrations $10^{-9}$ and $10^{-8} \mathrm{M}$ ) with CD3 and IL-2. As shown in Figure $5 E, \mathrm{CD}^{+}$proliferation was inhibited by $\mathrm{NE}$ at $10-9 \mathrm{M}$ and this inhibition was rescued by timolol maleate $(n=3$, $\mathrm{P}<0.05)$. The proliferation of $\mathrm{CD}^{+}$cells was also inhibited by $N E$ at $10-8 M(n=3, P<0.05)$, but could not be rescued by timolol maleate. Meanwhile, the proliferation of $\mathrm{CD} 8^{+}$ cells was inhibited by NE to some extent, although this was not statistically significant and the $\beta 2$-AR antagonist did not show any effect on the proliferation of $\mathrm{CD} 8^{+}$cells in the presence of NE (Figure $5 F$ ). These results indicated that $\beta 2-\mathrm{AR}$ were expressed in activated $\mathrm{T}$ cells and might be involved in the inhibition of $\mathrm{T}$ cell proliferation.

\section{The distribution of $\mathrm{CD}^{4} 5^{+}$immune cells and nerve fibers at the tumor site}

There are two ways the SNS conveys information to the peripheral tissues: firstly, using glucocorticoids from the hypothalamic-pituitary-adrenal (HPA) axis and, secondly, SNS neurotransmitters within organs. It is believed that neurites can grow into the tumor from the surrounding micro-environment. In the present study, we verified the nerve distribution characteristics at the tumor site. As shown in Figure 6A,B,C, NF-200+ fibers were densely distributed on the outer perimeter of the growing tumor island (Figure $6 A$ ), the region closely associated with the vasculature (Figure $6 B$ ), with some radiation into the tumor parenchyma (Figure 6C). CD $45^{+}$immune cells were observed to be densely distributed in the outer layer of the tumor island (Figure 6A), with some clustered in the central region of the tumor parenchyma. Interestingly, we found that the distribution patterns of the $\mathrm{CD} 45^{+}$population and the NF-200+ fibers were similar to each other, specifically, the regions with dense fibers such as the outer perimeter and associated vessels contained clusters of $\mathrm{CD} 45^{+}$cells (Figure $6 A, B, C$ ). In the $3 \mathrm{D}$ image of multiple-labeled IF staining, the $\mathrm{CD} 45^{+}$cells were located like beads on a string running with the nerve fibers (Figure $6 D, E$ ). These results indicated the nerve fibers were located in different regions of the tumor, often in association with $\mathrm{CD} 45^{+}$immune cells.

\section{Discussion}

The use of immune checkpoint therapies for the treatment of advanced cancers relies upon two strategies, namely, the inhibition of tumor cell proliferation and the promotion of $\mathrm{T}$ cell infiltration at tumor sites. In the present study, we firstly demonstrated that a combined sympathetic and CTLA-4 blockade is able to inhibit tumor growth melanoma-bearing mice, in a manner linked with $\mathrm{CD} 8^{+}$ $\mathrm{T}$ cell infiltration. Meanwhile, all $\beta 1-, \beta 2$ - and $\beta 3-\mathrm{AR}$ were found to be expressed in human PBMCs, activated $\mathrm{T}$ cells, monocytes, and monocyte-induced dendritic cells. $\beta 2-\mathrm{AR}$ was expressed in most $\mathrm{CD} 4^{+} \mathrm{T}$ cells with increased frequency in activated $\mathrm{CD} 8^{+} \mathrm{T}$ cells. Moreover, norepinephrine constrained $\mathrm{CD}^{+}{ }^{+}$and $\mathrm{CD} 8^{+} \mathrm{T}$ cell proliferation to some extent, and $\beta 2-\mathrm{AR}$ antagonists could reverse impaired $\mathrm{CD}^{+}$but not $\mathrm{CD} 8^{+}$cell proliferation. This suggested that a combination of SNS and CTLA4 inhibitors could be more beneficial to melanoma progression and might enhance the infiltration of $\mathrm{T}$ cells at the tumor site.

Therapeutic targeting of immune checkpoints is a means of modulating anti-tumor immunity, offering clinically valuable approaches to combating cancers. Checkpoint inhibitors, including antibodies against CTLA-4, PD-1, and PD-L1, can achieve long-lasting tumor regression, with a subset of patients achieving lasting remission. In the present study, we found that tumor size is negatively correlated with infiltrating $\mathrm{CD} 45^{+} \mathrm{CD} 3^{+}$and $\mathrm{CD} 45^{+} \mathrm{CD}^{+} \mathrm{CD} 8^{+} \mathrm{T}$ cell populations, indicating that, without the infiltration of $\mathrm{CD}^{+} \mathrm{T}$ cells, the tumor would grow more rapidly. Meanwhile, early anti-CTLA-4 treatment has shown better and more stable inhibition of tumor growth compared with the early or late anti-PD-1 groups. And increased CD $3^{+}$ and $\mathrm{CD}^{+} \mathrm{T}$ cells positive for CD45 was shown in the antiCTL4 group which is consistent with previous studies (24). These results indicated that early administration of antiCTLA-4 resulted in improved inhibition of tumor growth as well as enhancement of infiltrating cytotoxic $\mathrm{T}$ cell at the tumor site, leading us to choose anti-CTLA-4 antibodies to investigate the effects of combinational therapy. On the other hand, half of the mice treated with anti-PD-1 (days 1, 4 and 7) showed inhibition of tumor growth along with more infiltration of $\mathrm{CD}^{+} \mathrm{T}$ cells, while the other half did not. As the sample size was limited in this study, we hope to further confirm the findings in the future.

Chronic stress has been shown in epidemiological reports to correlate with outcomes in cancer patients (25). Chronic stress and depression are common in cancer patients owing to the incurable nature of the disease and the serious side-effects of chemotherapy and radiotherapy (26). Women with higher rates of stress in their lives are at a high risk of breast cancer development (27). Behavioral stress 

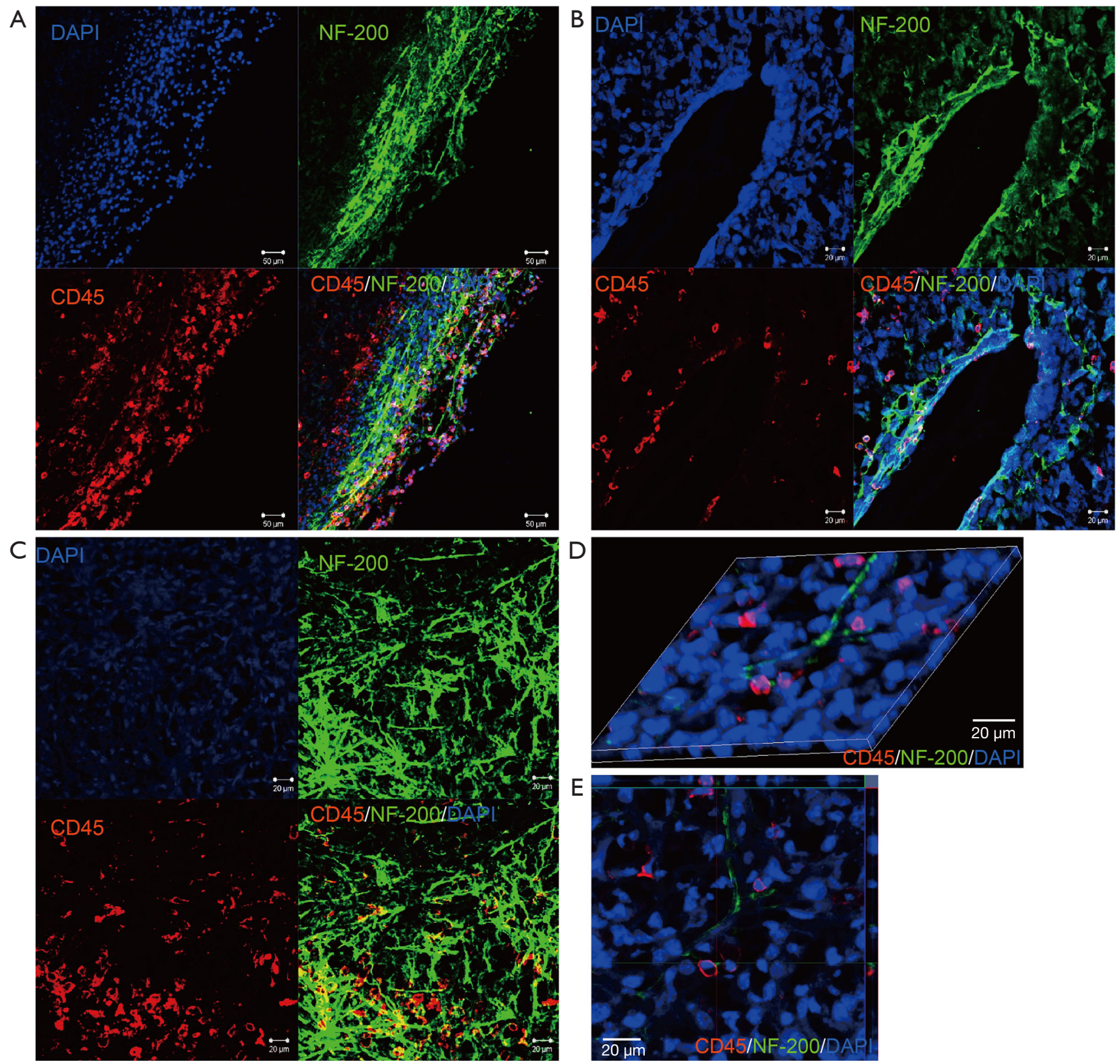

Figure 6 The distribution of $\mathrm{CD} 45^{+}$immune cells and nerve fibers in the tumor site. (A,B,C) Representative IF images labeled with antiNF-200 (green) and anti-CD45 (red) in the outer perimeter of tumor island (A), the region in close association with the vasculature (B) and the center region of tumor parenchyma (C). (D,E) Representative 3-dimensional IF images labeled with anti-NF-200 (green) and antiCD45 (red) in the central region of the tumor parenchyma. Scale bars, $20 \mu \mathrm{m}$. NF-200, neurofilament 200; IF, immunofluorescent.

in animals has also been shown experimentally to worsen disease including prostate, ovarian, breast, and pancreatic cancer (28-32). Epidemiological reports, however, show that $\beta$-adrenergic antagonist treatment is linked to alleviating these cancers (33-38). In the present study, we found that chemical sympathetic blockade using 6OHDA could inhibit tumor growth (Figure 3D) but was unable to alter the infiltration of $\mathrm{CD}^{+}$and $\mathrm{CD}^{+} \mathrm{T}$ cells, whereas combinatorial sympathetic and CTLA-4 blockade could both inhibit melanoma growth and enhance $\mathrm{CD}^{+} \mathrm{T}$ cell 
numbers, indicating that the sympathetic inhibitor not only inhibits the tumor growth which is consistent with previous studies but also assists $\mathrm{CD} 8^{+}$cells' survival and migration into the tumor after rescue by anti-CTLA-4 antibodies (Figure 3). Further studies using $\beta-\mathrm{AR}$ antagonists and antiCTLA-4 agents in tumor-bearing mice should carried out to confirm the sympathetic signaling targets on the tumor immune micro-environment.

After confirmation of the synergistic effect of the anti-CTLA-4 antibodies and sympathetic inhibitors, we attempted to identify the detailed pathways involved. It is known that the activation of SNS leverages neurotransmitters, neuropeptides, and/or hormones to modulate key cancer-associated pathways related to immunity, cell death, and oncogenesis (14). In the present study, we focused on the sympathetic regulation of tumorassociated immune micro-environment. Firstly, we demonstrated that $\beta 1-, \beta 2-$, and $\beta 3$-ARs were expressed in human PBMCs, activated T cells, monocytes, and monocyte-induced dendritic cells. Of the three receptors, inhibitors of the $\beta 2$-AR have been identified as beneficial for cancer patients, thus we further assessed $\beta 2$-AR levels in the activated $\mathrm{T}$ cell populations, and found that it was expressed in most $\mathrm{CD}^{+} \mathrm{T}$ cells with increased expression in activated $\mathrm{CD}^{+} \mathrm{T}$ cells (Figure 4), indicating that $\beta 2-\mathrm{AR}$ signaling may regulate $\mathrm{T}$ cell biology after $\mathrm{NE}$ secretion from the sympathetic nerve terminal.

Many reports have explored the link between the autonomic nervous system (ANS) and immunity, but only in the past decade has it been shown that stress and the ANS influence tumor-associated immunity and thereby promote tumor growth, progression, and metastasis $(5,35,39)$. There are several candidates for the SNS regulation of tumors, including macrophages, NK cells, and T cells which express different types of ARs. Macrophages have been previously considered as key players in mediating inflammation which promotes metastasis. For instance, $\beta$-adrenergic activation can induce the production of chemokines including chemokine (C-C Motif) ligand 2 (CCL2) and macrophage colony-stimulating factor (M-CSF), driving macrophage recruitment into tumors (15). Here, however, we concentrated on the effects of sympathetic neurotransmitters on the proliferation of activated $\mathrm{T}$ cells via NE/ $\beta 2-\mathrm{AR}$ signaling. Both the proliferation of activated $\mathrm{CD}^{+}$and $\mathrm{CD} 8^{+}$cells (Figure 5 ) were inhibited to some extent by $\mathrm{NE}$ at the range of 10-7 to 10-9 which is at the dose range of NE in human tissues and circulation. This inhibition of proliferation was reversed by the $\beta 2$-AR specific antagonist in $\mathrm{CD}^{+} \mathrm{T}$ cells but not in $\mathrm{CD}^{+} \mathrm{T}$ cells. In Figure 3, the administration of 6OHDA alone also has little effect on the CD $8^{+} \mathrm{T}$ cell population. These results conflicted with the in vivo findings that the sympathetic inhibitor could increase $\mathrm{CD}^{+}$ but not $\mathrm{CD}^{+} \mathrm{T}$ cell infiltration. There are several possible reasons for this discrepancy: firstly, $\mathrm{CD} 8^{+}$migration from nearby lymph nodes may be enhanced by the sympathetic inhibitor, secondly, a possible anti-apoptotic effect of the sympathetic inhibitor on the surviving infiltrating $\mathrm{CD}^{+} \mathrm{T}$ cells, and, thirdly, while NE is capable of inhibiting $\mathrm{CD}^{+}$ $\mathrm{T}$ cells via $\beta 2-\mathrm{AR}$ signaling, the inhibition of $\mathrm{NE}$ in the proliferation of $\mathrm{CD} 8^{+} \mathrm{T}$ cells may occur via alternate $\mathrm{AR}$ signaling.

The SNS regulates the tumor microenvironment primarily through either direct organ innervation and NE release from nerve terminals or via the HPA axis, through which the body detects stress leading to activation of the axis that, in turn. leads to hormone release and/ or sympathetic innervation, ultimately leading to adrenal glucocorticoid or adrenaline production to modulate physiological and immunological responses $(40,41)$. The ANS innervates many tumors directly, offering a means of interaction with the CNS. Experimental data have documented that neurotrophic factors including neural growth factor (42), brain-derived neural factor (43), and glial-derived neural factor (44) can be secreted by certain tumor and or stromal cells. These factors can, in turn, lead to active nerve fiber branching. The type of innervation that occurs depends on the nerve sources in the local microenvironment, though autonomic nerves including sympathetic and parasympathetic nerves predominate (13). SNS fibers typically infiltrate the outer perimeter of a growing tumor extending from proximal tissues, and in this study, we identified fibers within tumors and vasculature as well as fibers radiating into the tumor parenchyma. These fibers appear to be NF-200-positive but TH-negative. Further studies are needed to clarify the nature of these nerves, the $\mathrm{NE}$ and $\mathrm{AR}$ content, localization, and source in the tumor region. Interestingly, we found that $\mathrm{CD} 45^{+}$cells were located like beads on a string running alongside the nerve fibers. The localization and functional relationships between the subsets of immune cells, i.e., the $\mathrm{T}$ cells, and the infiltrating nerves warrants further study.

\section{Conclusions}

To conclude, we have demonstrated that a combined 
SNS and CTLA-4 blockade can inhibit tumor expansion in murine melanoma models accompanied by increased infiltration of $\mathrm{CD}^{+} \mathrm{T}$ cells. It is possible that sympathetic blockade via $\mathrm{AR}$ signaling assists $\mathrm{CD} 8^{+} \mathrm{T}$ cells survival and migration into the tumor after rescue by anti-CTLA-4 antibodies is responsible for the observed synergistic effect of the combinatorial therapy, offering a potentially valuable target for the future development of therapies targeting immune checkpoints.

\section{Acknowledgments}

Funding: This work was supported by the National Natural Science Foundation of China (NSFC) (No. 81704146), a Grant-in-Aid for Scientific Research and Scientific Research for Innovative Areas from the Ministry of Education, Culture, Sports, Science and Technology (MEXT) and the Ministry of Health, Labor and Welfare (MJ), and Tianjin Municipal Bureau of Labor and Social Security (No. 2018015).

\section{Footnote}

Reporting Checklist: The authors have completed the ARRIVE reporting checklist. Available at http://dx.doi. org/10.21037/tcr-20-2738

Data Sharing Statement: Available at http://dx.doi. org/10.21037/tcr-20-2738

Conflicts of Interest: All authors have completed the ICMJE uniform disclosure form (available at http://dx.doi. org/10.21037/tcr-20-2738). Dr. MJ reports personal fees from Astrazeneca Japan, outside the submitted work. The other authors have no conflicts of interest to declare.

Ethical Statement: The authors are accountable for all aspects of the work in ensuring that questions related to the accuracy or integrity of any part of the work are appropriately investigated and resolved. The study was conducted in accordance with the Declaration of Helsinki (as revised in 2013). The study was approved by the Human Ethics Committee of Keio University Medical School (No. 2013-0122-3) and informed consent was taken from all the patients. Experiments were performed under a project license [NO.: 09006-(8)] granted by the Institutional Animal Care and Use Committee of Keio University for the care and use of animals.
Open Access Statement: This is an Open Access article distributed in accordance with the Creative Commons Attribution-NonCommercial-NoDerivs 4.0 International License (CC BY-NC-ND 4.0), which permits the noncommercial replication and distribution of the article with the strict proviso that no changes or edits are made and the original work is properly cited (including links to both the formal publication through the relevant DOI and the license). See: https://creativecommons.org/licenses/by-nc-nd/4.0/.

\section{References}

1. Jemal A, Bray F, Center MM, et al. Global cancer statistics. CA Cancer J Clin 2011;61:69-90.

2. Lillberg K, Verkasalo PK, Kaprio J, et al. Stressful life events and risk of breast cancer in 10,808 women: a cohort study. Am J Epidemiol 2003;157:415-23.

3. Reiche EM, Nunes SO, Morimoto HK. Stress, depression, the immune system, and cancer. Lancet Oncol 2004;5:617-25.

4. Cole SW, Nagaraja AS, Lutgendorf SK, et al. Sympathetic nervous system regulation of the tumour microenvironment. Nat Rev Cancer 2015;15:563-72.

5. Hanoun M, Maryanovich M, Arnal-Estapé A, et al. Neural regulation of hematopoiesis, inflammation, and cancer. Neuron 2015;86:360-73.

6. Grytli HH, Fagerland MW, Fosså SD, et al. Use of $\beta$-blockers is associated with prostate cancer-specific survival in prostate cancer patients on androgen deprivation therapy. Prostate 2013;73:250-60.

7. Powe DG, Voss MJ, Zänker KS, et al. Beta-blocker drug therapy reduces secondary cancer formation in breast cancer and improves cancer specific survival. Oncotarget 2010;1:628-38.

8. Barron TI, Connolly RM, Sharp L, et al. Beta blockers and breast cancer mortality: a population- based study. J Clin Oncol 2011;29:2635-44.

9. Aydiner A, Ciftci R, Karabulut S, et al. Does beta-blocker therapy improve the survival of patients with metastatic non-small cell lung cancer. Asian Pac J Cancer Prev 2013;14:6109-14.

10. Diaz ES, Karlan BY, Li AJ. Impact of beta blockers on epithelial ovarian cancer survival. Gynecol Oncol 2012;127:375-8.

11. De Giorgi V, Grazzini M, Gandini S, et al. Treatment with $\beta$-blockers and reduced disease progression in patients with thick melanoma. Arch Intern Med 2011;171:779-81.

12. Ceyhan GO, Bergmann F, Kadihasanoglu M, et 
al. Pancreatic neuropathy and neuropathic pain--a comprehensive pathomorphological study of 546 cases. Gastroenterology 2009;136:177-186.e1.

13. Magnon C, Hall SJ, Lin J, et al. Autonomic nerve development contributes to prostate cancer progression. Science 2013;341:1236361.

14. Xu Z, Shioda S, Masahisa J, et al. Role of the Autonomic Nervous System in the Tumor Micro-Environment and its Therapeutic Potential. Curr Pharm Des 2017;23:1687-92.

15. Armaiz-Pena GN, Gonzalez-Villasana V, Nagaraja AS, et al. Adrenergic regulation of monocyte chemotactic protein 1 leads to enhanced macrophage recruitment and ovarian carcinoma growth. Oncotarget 2015;6:4266-73.

16. Topalian SL, Drake CG, Pardoll DM. Immune checkpoint blockade: a common denominator approach to cancer therapy. Cancer Cell 2015;27:450-61.

17. Sharma P, Allison JP. The future of immune checkpoint therapy. Science 2015;348:56-61.

18. Sunshine J, Taube JM. PD-1/PD-L1 inhibitors. Curr Opin Pharmacol 2015;23:32-8.

19. Wolchok JD, Kluger H, Callahan MK, et al. Nivolumab plus ipilimumab in advanced melanoma. N Engl J Med 2013;369:122-33.

20. Le DT, Lutz E, Uram JN, et al. Evaluation of ipilimumab in combination with allogeneic pancreatic tumor cells transfected with a GM-CSF gene in previously treated pancreatic cancer. J Immunother 2013;36:382-9.

21. Haruta M, Tomita Y, Imamura Y, et al. Generation of a large number of functional dendritic cells from human monocytes expanded by forced expression of cMYC plus BMI1. Hum Immunol 2013;74:1400-8.

22. Xu Z, Ohtaki H, Watanabe J, et al. Pituitary adenylate cyclase-activating polypeptide (PACAP) contributes to the proliferation of hematopoietic progenitor cells in murine bone marrow via PACAP-specific receptor. Sci Rep 2016;6:22373.

23. Lucas D, Scheiermann C, Chow A, et al. Chemotherapyinduced bone marrow nerve injury impairs hematopoietic regeneration. Nat Med 2013;19:695-703.

24. van Elsas A, Hurwitz AA, Allison JP. Combination immunotherapy of B16 melanoma using anti-cytotoxic T lymphocyte-associated antigen 4 (CTLA-4) and granulocyte/macrophage colony-stimulating factor (GM$\mathrm{CSF}$ )-producing vaccines induces rejection of subcutaneous and metastatic tumors accompanied by autoimmune depigmentation. J Exp Med 1999;190:355-66.

25. Antoni MH, Lutgendorf SK, Cole SW, et al. The influence of bio-behavioural factors on tumour biology: pathways and mechanisms. Nat Rev Cancer 2006;6:240-8.

26. Cole SW. Nervous system regulation of the cancer genome. Brain Behav Immun 2013;30 Suppl:S10-8.

27. Lutgendorf SK, Sood AK. Biobehavioral factors and cancer progression: physiological pathways and mechanisms. Psychosom Med 2011;73:724-30.

28. Thaker PH, Han LY, Kamat AA, et al. Chronic stress promotes tumor growth and angiogenesis in a mouse model of ovarian carcinoma. Nat Med 2006;12:939-44.

29. Sloan EK, Priceman SJ, Cox BF, et al. The sympathetic nervous system induces a metastatic switch in primary breast cancer. Cancer Res 2010;70:7042-52.

30. Schuller HM, Al-Wadei HA, Ullah MF, et al. Regulation of pancreatic cancer by neuropsychological stress responses: a novel target for intervention. Carcinogenesis 2012;33:191-6.

31. Prasad SM, Eggener SE, Lipsitz SR, et al. Effect of depression on diagnosis, treatment, and mortality of men with clinically localized prostate cancer. J Clin Oncol 2014;32:2471-8.

32. Eng JW, Reed CB, Kokolus KM, et al. Housing temperature-induced stress drives therapeutic resistance in murine tumour models through $\beta 2$-adrenergic receptor activation. Nat Commun 2015;6:6426.

33. Cakir Y, Plummer HK, Tithof PK, et al. Beta-adrenergic and arachidonic acid-mediated growth regulation of human breast cancer cell lines. Int J Oncol 2002;21:153-7.

34. Saeed RW, Varma S, Peng-Nemeroff T, et al. Cholinergic stimulation blocks endothelial cell activation and leukocyte recruitment during inflammation. J Exp Med 2005;201:1113-23.

35. Nance DM, Sanders VM. Autonomic innervation and regulation of the immune system (1987-2007). Brain Behav Immun 2007;21:736-45.

36. Scheiermann C, Kunisaki Y, Lucas D, et al. Adrenergic nerves govern circadian leukocyte recruitment to tissues. Immunity 2012;37:290-301.

37. Mestanik M, Mestanikova A, Visnovcova Z, et al. Cardiovascular sympathetic arousal in response to different mental stressors. Physiol Res 2015;64 Suppl 5:S585-94.

38. Visnovcova Z, Mokra D, Mikolka P, et al. Alterations in vagal-immune pathway in long-lasting mental stress. Adv Exp Med Biol 2015;832:45-50.

39. Li S, Sun Y, Gao D. Role of the nervous system in cancer metastasis. Oncol Lett 2013;5:1101-11.

40. Elenkov IJ, Wilder RL, Chrousos GP, et al. The sympathetic nerve--an integrative interface between two supersystems: the brain and the immune system. 
Pharmacol Rev 2000;52:595-638.

41. Kenney MJ, Ganta CK. Autonomic nervous system and immune system interactions. Compr Physiol 2014;4:1177-200.

42. Pufall MA. Glucocorticoids and Cancer. Adv Exp Med Biol 2015;872:315-33.

Cite this article as: Wang $\mathrm{B}, \mathrm{Xu} \mathrm{Z}$, Sunthamala N, Yaguchi T, Huang J, Kawakami Y, Gong Y, Tang H, Li S, Guo Y, Guo Y, Jinushi M. Combinatorial sympathetic and cytotoxic T-lymphocyte-associated protein 4 (CTLA-4) blockades inhibit the murine melanoma growth by targeting infiltrating $\mathrm{T}$ cells. Transl Cancer Res 2021;10(2):899-913. doi: 10.21037/tcr-20-2738
43. Tilan J, Kitlinska J. Neuropeptide Y (NPY) in tumor growth and progression: Lessons learned from pediatric oncology. Neuropeptides 2016;55:55-66.

44. Ali A, Pisipati S, Tewari A. Words of wisdom: Re: Autonomic nerve development contributes to prostate cancer progression. Eur Urol 2014;65:665-6. 